\title{
The monitoring of world heritage sites during construction works in their vicinity: the case of Casa Milà and of the Church of Sagrada Familia in Barcelona, Spain
}

\author{
W. Jäger ${ }^{1,2}$, T. Burkert ${ }^{2}$, B. Boekhoff ${ }^{1} \&$ T. Bakeer $^{1}$ \\ ${ }^{I}$ TU Dresden, Germany \\ ${ }^{2} J a ̈ g e r$ Ingenieure GmbH Radebeul, Germany
}

\begin{abstract}
World Heritage Sites declared by UNESCO can be in danger when construction works are planned and implemented in their vicinity. Works above the ground are mostly excluded by the declaration due to the visible influence on the appearance of the World Heritage Building or Complex. However, in the case of street works or of the execution of underground buildings there is no limitation or prescription. These works can influence the stability or the load bearing behaviour of the building during the execution or afterwards. That's why it is necessary to consider the interaction of the planned works with the monument. The time during the construction should also be considered for long term effects. The problems which can arise in such a case will be explained on the example of the construction of the high-speed train tunnel in the vicinity of Temple Sagrada Familia and to Casa Milà in Barcelona Spain. At the end conclusions are drawn for future declarations of World Heritage Monuments and necessary monitoring missions. The responsibility for the declaration as well as for the monitoring lies in the hands of the state site of the respective country which should consider the outcome of this case study very early.

Keywords: UNESCO world heritage, monitoring, tunnelling works, structural behaviour, analysis, damage prevention.
\end{abstract}




\section{Introduction}

France and Spain decided to extend their railway network and connect it with each other. In this way a direct train connection between Madrid, Saragossa, Barcelona, Paris and London should be possible (Wikipedia [1]). For this it was necessary to extend the railway line from Barcelona to Girona, Figueres and Perpignan in France and also through the city of Barcelona itself. There have been different variants to connect the railway before Barcelona was decided upon.

The decision was made to choose the route through the city along the Casa Mila and Sagrada Familia. After the accident in Cologne in March 2009 during tunnelling works the opposers were worrying about a repetition of such an unforeseen event in vicinity to both the World Heritage Buildings (UNESCO [2]). The UNESCO was called to check the situation and carry out a monitoring mission. The author and Rolf Katzenbach were mandated to carry out that mission ending in a recommendation for an independent supervision and control of the tunnelling project as well as execution of the works, so that no impact on the World Heritage Objects can happen. That task was taken over from a team of Rolf Katzenbach and Wolfram Jäger.

\section{The world heritage}

A UNESCO World Heritage Site is a place that is listed by UNESCO as of special cultural or physical significance (UNESCO [2]). The list is maintained by the international World Heritage Programme administered by UNESCO World Heritage Committee (WHC). The program catalogues, names, and conserves sites of outstanding cultural or natural importance to the common heritage of humanity.

The declaration and the participation at the program should guarantee the existence and the appearance of the World Heritage Site also for future generations. If a site is selected and listed by the WHC it belongs to the whole of humankind and not only the corresponding country can decide about the future and preservation of it. But the state party of the country is responsible for the maintenance and has to do all for conserving the site (Wikipedia [3]).

The church of Sagrada Familia is listed as World Heritage as well as Casa Milà as the main works of the Catalan architect Antoni Gaudi [4, [5].

\subsection{Sagrada Familia}

Sagrada Familia is officially named in Catalan the "Basílica i Temple Expiatori de la Sagrada Família". It is a Roman Catholic Church situated within the city district Eixample in the centre of Barcelona (Wikipedia [6], Bonet i Armengol [7]). The construction work for it began in 1882. In 1883 Gaudí took over the responsibility for the design, planning and execution of the church. He worked till his death in 1926 for this outstanding project. The building is not yet finished 
and the works are in progress now. The current aim is to finish it by the 100years-aniversery of the death of Gaudi.

At first the building master followed the neogothic principles of his predecessor that can be seen in the Crypt and the apse. Than he changed his plans totally after receiving a remarkable donation which allowed it to realize a new design principle based on the forms taken from the nature. He joined together with some others in his own architectural style named as Catalan Modernism. He further developed the basic ideas of the gothic to take over the forms of the nature and he discovered the hyperbolic paraboloid as a regular shape and introduced it in his structural forms. He had known the disadvantages of the building material masonry in that it cannot transmit any tensile forces and used structural forms following the chain line and which are under compression. He applied the graphically structural analysis and built hanging models to check his structures and the load flow. (See also Wikipedia [5] and Tomlow [9]).

When Gaudi passed away the crypt, the exterior wall of the apse and the four steeples of the nativity facade were erected (see Figure 1:b). The complete finishing of these towers followed in 1936 and during the civil war the building activities were suspended after a trial to destruct the church and the workshop with all design drawings, models and craftsman tools.

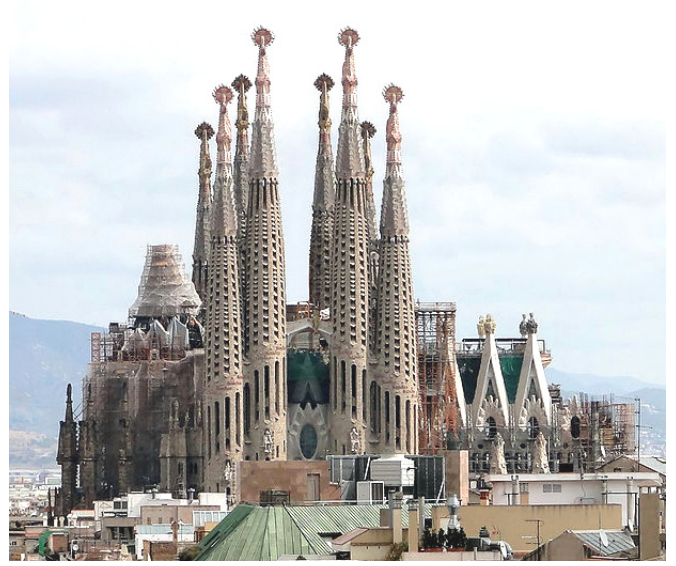

a)

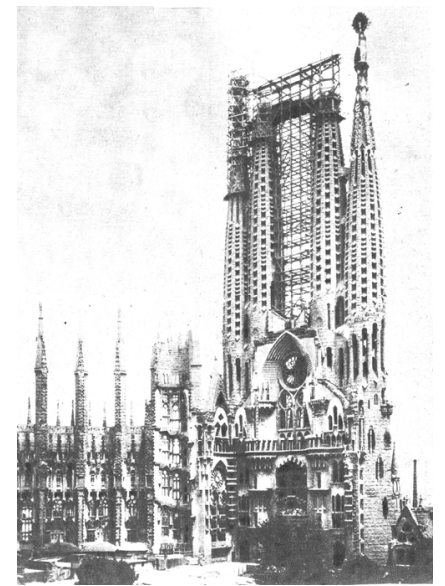

b)

Figure 1: a) View over the roofs on Sagrada Familia; b) view in the inner room of the church with parts originally constructed by Gaudi (1926).

After World War II, in 1954 the construction works for the Passion facade on the western transept began. The construction of the main nave was started in 1978 and the vaults were completed in 2000, then followed the vaults in the transept and the apse. Since 2006 construction activities are focusing on the main steeple over the centre of the church as well as the Glory facade at the southern part of the main nave. The main steeple is planned with a height of $170 \mathrm{~m}$. The outer dimensions of the basilica are around $90 \times 60 \mathrm{~m}^{2}$. During the last two years 
the building activities have been concentrated also on the finishing of the inner room and to prepare the start of the use as church. On $7^{\text {th }}$ of November 2010 , Pope Benedict $\mathrm{XVI}^{\text {th }}$ inaugurated the church with much publicity.

\subsection{Casa Mila}

Gaudi was asked to design an outstanding and modern dwelling house for the Milà-family. The construction started in 1905 and lasted till 1912 (Wikipedia [10]). The house is from the structural point of view a skeleton building consisting of masonry or stone columns bearing steel beams in the form of a grillage. Between the girders flat brick vaults were spanned which are covering the room and acting as support for the floor.

In connection with the retrofitting measures carried out in the first half of the 1990s within the cellar level, selected columns were reinforced by adding highresistance mortar in order to increase the load bearing capacity. Material tests on the applied brickwork and/or limestone columns revealed that compressive strength values were very similar to the one's that had been used by Gaudí and his colleague Jaume Bayó for the primary structural calculation (Asarta [11]), a matter that coincides with the fact that Gaudi had chosen the blocks from the quarry himself according to the specific needs of the structural elements. As a result different limestone varieties can be found within the columns in the different levels as well as in the façade.

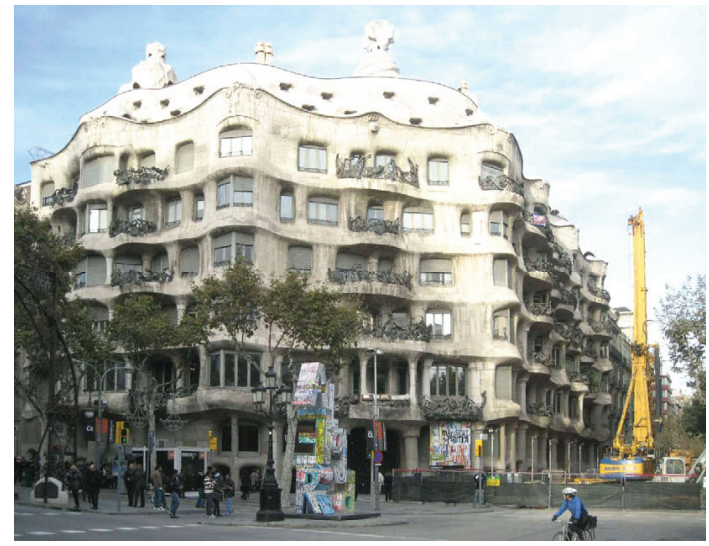

a)

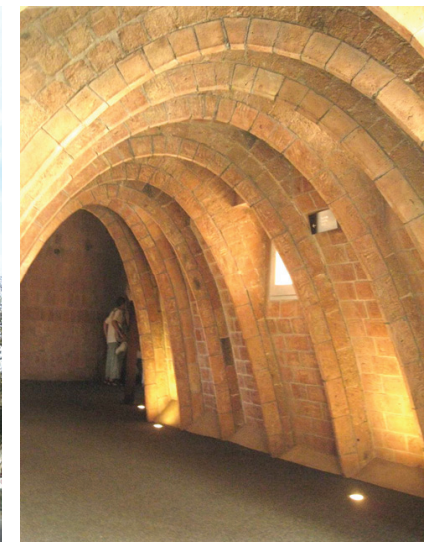

b)

Figure 2: a) Casa Mila during the bore pile works in October 2010; b) roof structure of Casa Mila in form of ribbed shells made by masonry.

The façade looks like it is made from one stone but it is made by natural stone plates finally overworked and finished in place. The façade plates are anchored by steel connectors fastened at the skeleton. The building provided for the accommodation for the Milà family in the main storey but also housed shelter for rented apartments. Now the building owner since 1986 is the bank Caixa 
Catalunya. The building houses mainly offices, apartments, shops, and exhibition areas. Some years ago a general restoration was done and documented. It gave the possibility to get an insight into the inner structure of the entire building.

Casa Milà has an outstanding and unique value due to Gaudì's creative contribution to the development of building technology and architecture itself, as well as to the formation of the Catalan Modernisme as architectural style while at the same time appreciating the uniqueness of the structure itself (Wikipedia [10] and Asarta [11]). With the approach to design open-plan floors with help of the bearing skeleton he reached more freedom for the utilisation of the building. Gaudí followed once more his own concept of space. As a result structural walls solely exist towards the neighbouring buildings and partially in connection/conjunction with the main staircases. The stabilisation of the skeleton is in this way rare but sufficient.

Structurally remarkable, in particular the keen roof structure of Casa Milà, which is made of a series of masonry arches that vary in span and height. The nearly 270 parabolic arches in the attic floor leave the impression of a ribbed skeletal cavity. The mostly single-layered brick masonry arches rest on the ceiling below and are stiffened in longitudinal direction by brick rows that connect the keystones as well as the imposts of the arches.

\subsection{Remarks to the declaration of cultural world heritage}

Due to its outstanding value selected works of Antoni Gaudi were declared as Cultural World Heritage in 1984 caused by its uniqueness and brilliance. Among them were the Park Güell, Palau Güell, Casa Milà, all in Barcelona (Wikipedia [2]). In 2005, with the original by Gaudi, were constructed parts of Sagrada Familia (Crypt und Nativity Façade), Casa Vicens, Casa Batlló (all in Barcelona) and the Crypt of Colonia Güell (in Santa Coloma de Cervelló) (Wikipedia [5]).

The application documents for the preparation of the decision on acceptance by the WHC of the UNESCO has to be done by the state applying. The site should fulfil established criteria (Wikipedia [3]). The check and evaluation of the documents by one or more independent UNESCO-Experts follows after submission. A resolution for the WHC will be prepared on the basis of the expert reports which will be decided or not at the next meeting of the WHC. Sites under risk will be moved to the red list where they will sharper under control.

In the declaration of Cultural World Heritage a core zone with the heritage parts or object being World Heritage will be formed which is surrounded and protected by a buffer zone. In the documents which the applicant is delivering to the UNESCO he has to justify the heritage character and to describe the measures for its own durable preservation. The so called buffer zone serves for the protection of the surrounding and appearance of the World Heritage. This is a spatial determined region within this the World Heritage is located. In this buffer zone the perception and the experience of the World Heritage Place should be guaranteed. Its task is to protect the directly associated field and the historic views and outlooks against the strong pressure of modern development and traffic increases. It also contributes to the preservation and enhancement of urban 


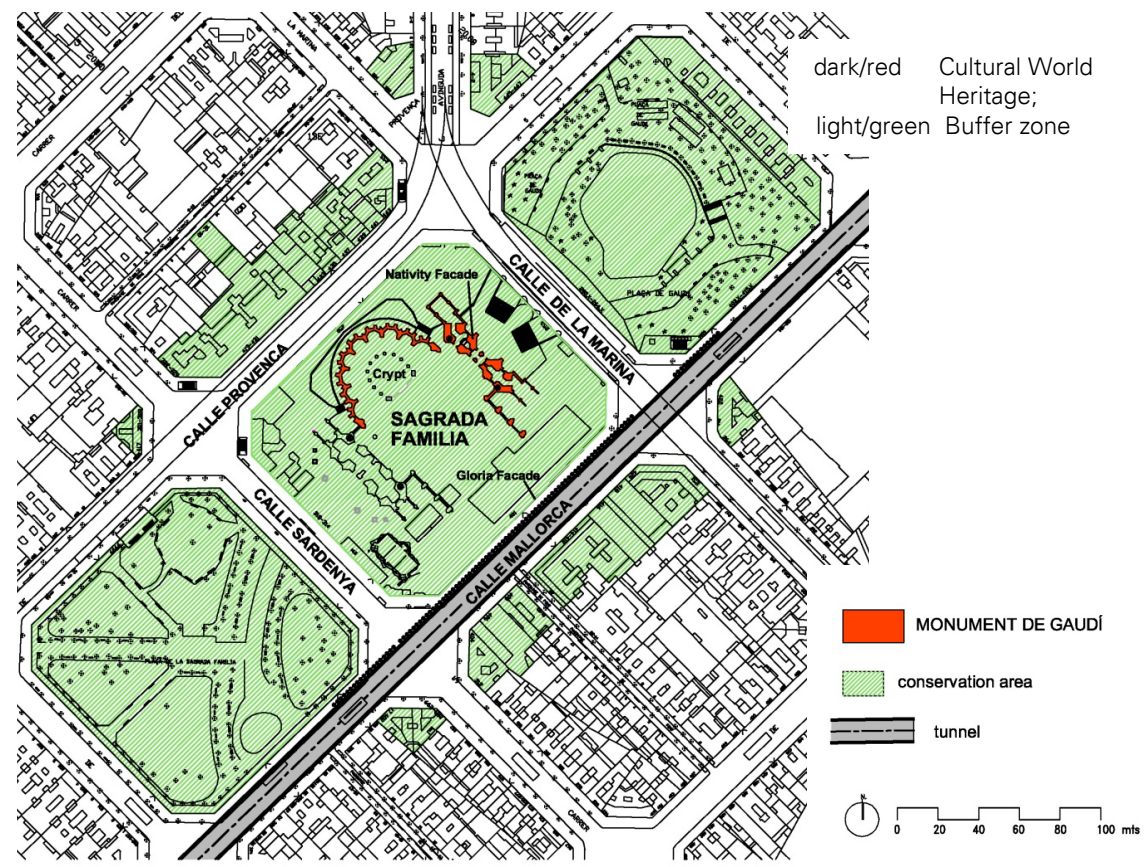

Figure 3: Location of the tunnel and of cultural world heritage parts of Sagrada Familia (UNESCO [12]).

quality. The buffer zone shall protect the World Heritage against impairment by physical structures with an inadequate height, cubing and design (translated citation from Hildesheim [12]).

In the accepted declaration as World Heritage the street spaces were taken off from the buffer zone of Sagrada Familia and Casa Milà. This was a disadvantage which made it more difficult to enforce necessary measures in connection with the planned tunnel construction. But not only the introduction of the street spaces in the buffer zone would be enough if not also the allowable changes or interventions beneath the terrain level had been defined.

This is a gap for the structural point of view in dealing with Cultural World Heritage and their buffer zones. According to the opinion of the author the declaration and the grounds of construction activities in vicinity to the cultural heritage as well as the allowable activities in the buffer zone can only be done interdisciplinary. That means that also engineers should be involved in the application and the proofing, which can contribute important things from their own point of view under weighing of structural aspects with cultural and architectural ones.

In the case of declaration for Sagrada Familia's original parts only art historically and architectural problems were considered. The argument for neglecting of the street spaces was that there was only the entrance buildings for 
the metro were repairs or changes only would be possible, if the UNESCO will allow this in a complicated procedure (or not).

\section{Tunnel construction and safety precautions}

\subsection{Tunneling technology}

The soil in the area beneath both buildings is soft, mostly gravel or clay in different layers and constituents. That is why the Earth Pressure Balance Technology was foreseen to execute the tunnel (also nearby Sagrada Familia and Casa Mila, (see Wikipedia [15]). The general idea of this technology is to reduce any settlement due to unstressing of the soil and the loss of material by pressure and injection. It has a high level and needs experience and consequent preparation so that no unforeseen loss of pressure can happen.

\subsection{Bore pile wall in front of the world heritage buildings}

With a view on the outstanding value of Sagrada Familia during the planning of the tunnel construction an additional protection measure in the form of a bore pile wall in front of the church was foreseen. The bore piles were built in with a distance between each other from around $50 \mathrm{~cm}$ to allow the flow of the groundwater through it.

The working principle should be that in the case of settlement over the tunnel the soil nearby the pile wall hangs up at the row surface of the bore piles. This should reduce the settlement behind the pile wall and the additional loads due to the hanging up of the soil will be transmitted through the piles head and circumferential surface beneath the tunnel. Furthermore in emergency cases limited material loss by pressure reduction or other unforeseen events should have no impact on the foundation and the structure of the building nearby. That's why all the tops will be connected by a continuous rc-beam to level any unequal action on the protection wall.

After checking this solution it was also planned and executed in front of Casa Milà but with smaller dimensions than in the case of Sagrada Familia.

\section{Check of the project}

The task for the team of Rolf Katzenbach and Wolfram Jäger embedded in a Board of national and international experts was to check the entire solution with their different parts independent and to supervise and monitor the execution of all tunneling works so that any impact on the World Heritage Site could be avoided. Human mistakes can be prevented and the implementation of the 


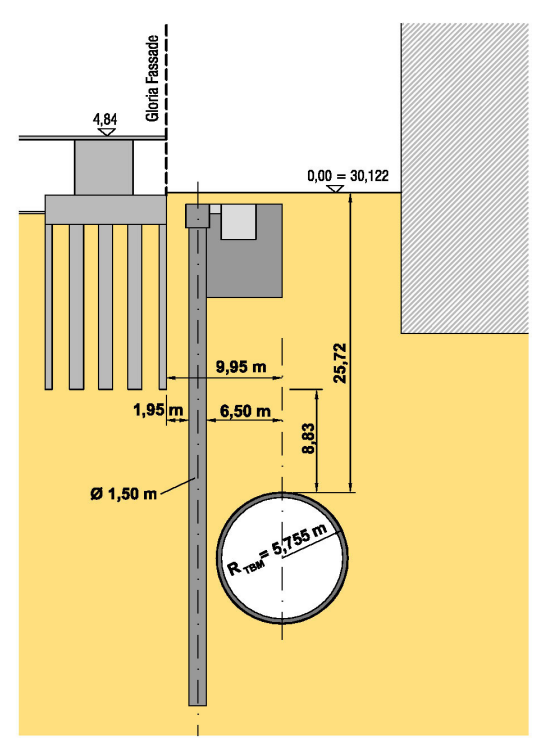

a)

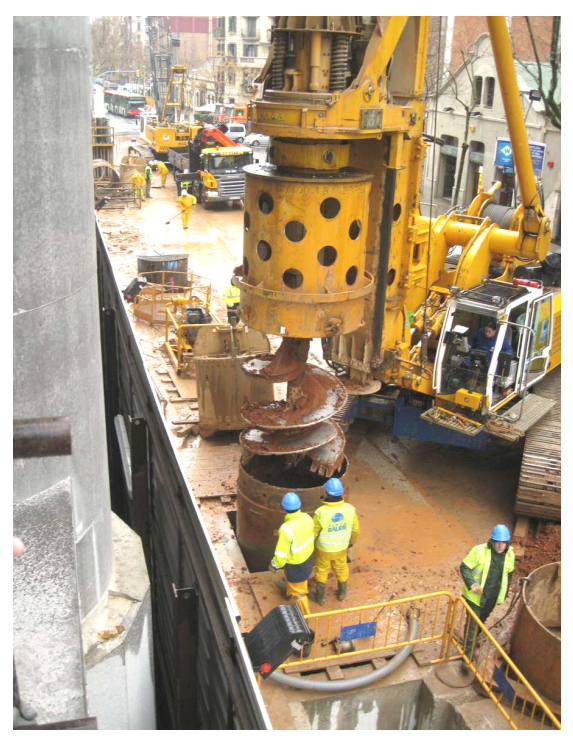

b)

Figure 4: Disintegrated bore pile wall a) Cross section with location to the foundation of Sagrada Familia [16] b) Execution of works in front of the Glory Façade (south main entrance).

planning and execution on current state of the art can be guaranteed by this. Unknown things remaining as risk as well as the not detected inhomogeneities in the subsoil.

\subsection{Effectiveness of the protection bore pile wall}

The effectiveness of the planned protection wall in the form of the open bore pile wall in front of the World Heritage Buildings could be confirmed by independent numerical calculations. For this it was necessary to create a model which considered the structure as well as the subsoil in its interaction.

\subsection{Behavior of the buildings and influence of soil settlement}

The behind the bore pile wall remaining settlements should have no impact on the World Heritage building or even parts of it. One result of the independent check was the definition of threshold values which could be allowed so that no damage or influence could be seen. The result of the executed investigations was that for some measuring points the in Spain well known MINTRA limits [18] should be more specified under consideration of the special geometry as well as under application of the observational method according to EC 7 [19]. It implies the calibration of calculated models and results in accordance to the ground conditions found during the execution of works. The MINTRA values are based 
on Spanish experiences and known works from literature (Boscardin [20] and Burland [21]).

A comprehensive set of numerical simulations was carried out to study the behavior of the buildings and to clarify the zones under risk. Also worst case scenarios were investigated (Peinelt [17] and Bakeer and Schöps [22]). It could be shown that the both buildings can bear the settlement in the forecasted height. Different modeling strategies were used under input parameter variation. In the case of Sagrada Familia also different construction stages were investigated. Figure 5: gives an insight in the modeling steps and shows the CAD-model for defining the geometry as well as the FE-model for structural analysis of the entire building or parts of it, here a bar model Casa Milà. While for Sagrada Familia shell and solid elements were used, for Casa Milà also a bar model was reasonable. The analysis was carried out in the elastic stage as well as - if necessary - in the nonlinear stage. The interaction between the subsoil and the building was considered stepwise or in the case of Sagrada Familia also together in one model.

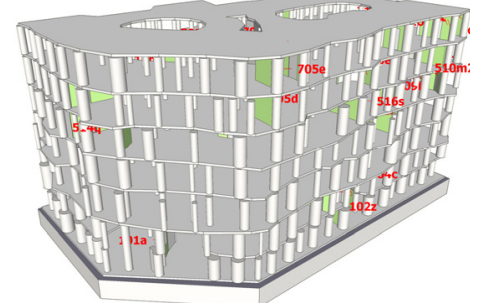

a) CAD-model of the building geometry

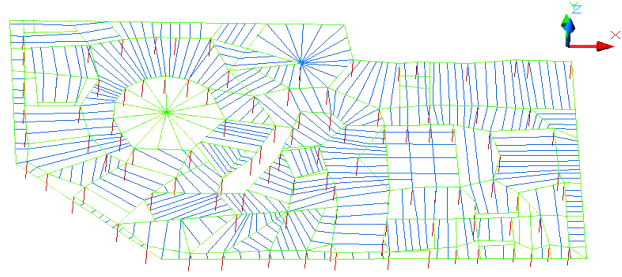

b) Bar model of the basement to demonstrate the principle structure

Figure 5: Models for the analysis of the load bearing behaviour of Casa Milà (Peinelt [17]).

\subsection{Monitoring of the both buildings and the construction works}

Due to the outstanding value of both buildings from the responsible engineers a deeper monitoring and data recording was foreseen than for the other surrounding buildings.

The main elements of the monitoring system during the tunnelling works in vicinity of the both World Heritage Buildings were:

1. Online monitoring all over the day of the working parameters of the TBM. The parameters of the TBM performance are the first indicators of a possible unforeseen situation during the tunnel construction.

Used devices were the master control station in the TBM and his duplicate at the site office. All data were continuously recorded electronically and evaluated.

2. Monitoring of underground structures of the existing metro tunnel L2 east from Sagrada Familia

by means of geodetic levelling and automatic levelling at the tracks in the tunnel. 
3. Monitoring of the deformations of the soil at the surface and in the deeper layers

by use of levelling marks and extensometers. The measurement was carried out approximately 4-5 times within 24 hours during the TBM passage (see Figure 6).

4. Monitoring of the deformations of the buildings in vicinity of and at the both buildings itself

by means of levelling marks attached to the outer walls and inner parts as well as automatic total stations surveying prisms on the facades. The displacements of those prisms are obtained automatically every 30 minutes.

5. Monitoring of the deformations of the roof in Casa Milà

by means of manual observations of possible horizontal deformations of the brick arches in the attic level with laser distance measurer. The measurements were carried out starting in January 2011 and were continued with adapted frequencies according to the progress of the TBM.

6. Additionally, in the basement of Sagrada Familia, in the area of the Glory facade, 12 levelling marks were situated.

The precision levelling was executed app. 3 times a day during the passage of the TBM by tachymeter theodolite with automatically recording of data from the type LEICA DNA 03 and invar surveyor's rod (see Figure 11: 11).

7. Monitoring of existing cracks and selected joints in Sagrada Familia by means of a crack monitoring system which was especially designed and implemented for the passage of the TBM. The installed system inside Sagrada Familia focused on the possible impact of the temple close-by the tunnel axis and on the UNESCO World Heritage Part of the temple. The crack measurement devices were mostly located in the Nativity façade, the choir and the original part of the cloister. Due to the specific structure of the naives and the Glory Façade, a further focus was set on the construction/movement joint between Glory facade and the main nave in order to detect firsthand any movement of this very high and slim part of the façade related to the tunnel construction process. For this optical monitors (see Figure 8a) as well as traditionally crack monitors as redundant addition were used. For the recording of possible movements of the cracks at the apse and the cloister transducers Figure 8b) came into operation instead of optical devices.

During the passing of the TBM the crack monitoring of the church was executed 24 hours a day. The main part of the crack monitoring devices with electronically recording was read out online every 5 minutes. The manual crack monitors were controlled app. 4 times a day. A section of the instrumentation plan is shown in Figure 7. 


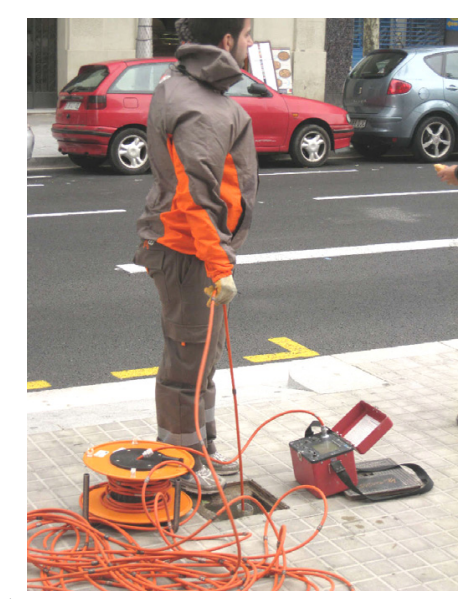

a)

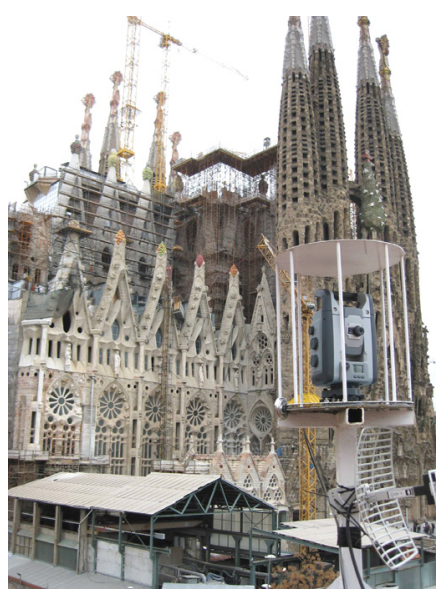

b)

Figure 6: Measuring devices at Sagrada Familia a) extensometer; b) tachymeter theodolites working automatically (Cyclop).
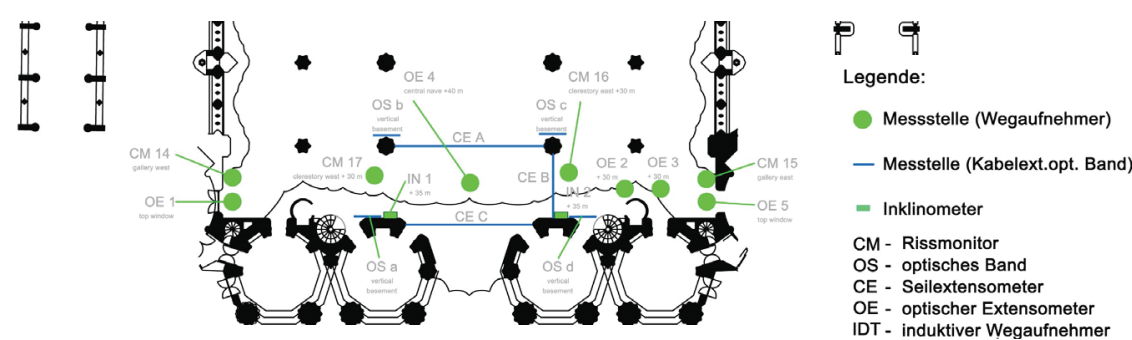

Figure 7: $\quad$ Layout plan of the Glory Façade with measuring points.

8. For a selection of climatic influences all meteorological data were recorded continuously by wind-, temperature and humidity sensors.

9. Due to the objection against the bore pile wall from other sides, a monitoring of the ground water level was executed before the TBM passed the building of Sagrada Familia

by normal gauges. There was an interruption of the recording during the passing of the TBM necessary due to technological reasons. The measuring was continued by new installed wells nearby the previous ones.

Post-monitoring was carried out until stabilization of movements or at least three months after passing the building by the TBM.

The different parts of the monitoring formed a redundant system and were analysed and interpreted permanently, also considering the interrelation to each other. The monitoring system was designed in such a way, that it would allow to detect any irregularities and to react immediately to any unforeseen situation. 


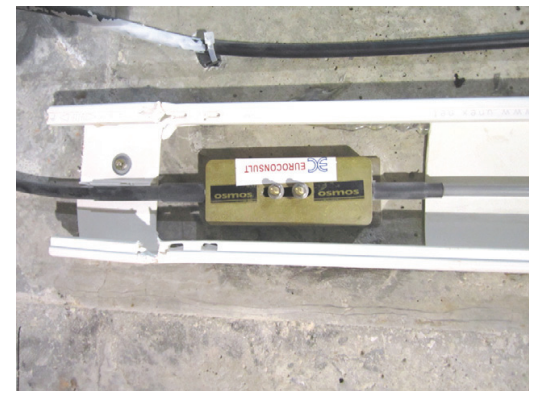

a)

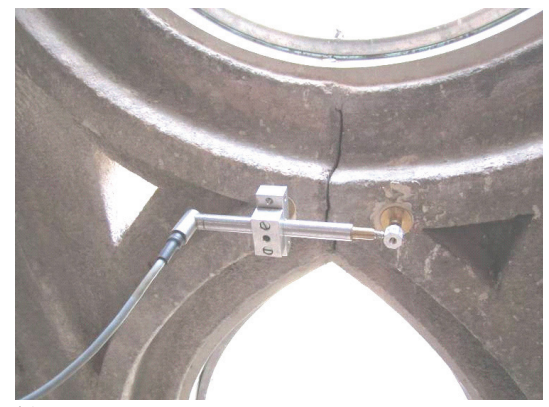

b)

Figure 8: a) Optical sensor; b) transducer.

a)

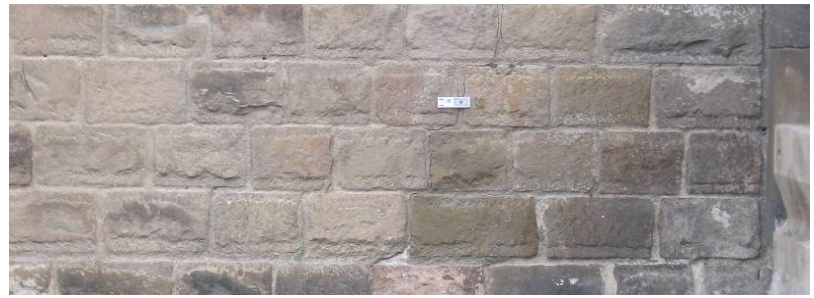

b)

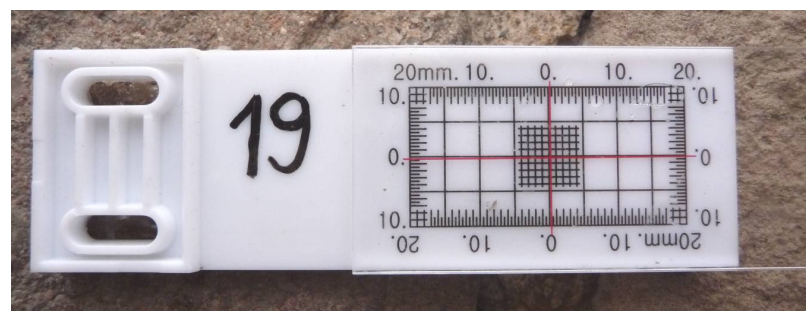

Figure 9: Traditional crack monitors a) location on a crack in the exterior wall of the cloister; b) view on the monitor in the 0 -position.

\section{Monitoring results}

\subsection{Tunneling works}

The passing of the TBM in vicinity to the Temple of Sagrada Familia over the distance of the bore pile wall took place in the time from $3^{\text {rd }}$ to $17^{\text {th }}$ of October 2010. The protection wall of Casa Milà was reached on $18^{\text {th }}$ of February 2011. The machine passed it at $20^{\text {th }}$ of February 2011 . The velocity of the TBM was as average value $33 \mathrm{~m} /$ day in the sandy soil respectively $17,5 \mathrm{~m} /$ day in the more clayey soil along Sagrada Familia and 34,4 m per day along Casa Milà. 
Because of the precise preparation and control of the tunneling works the settlement due to the tunneling works could be minimized. The absolute size lay beneath the forecasted values.

The extensometers in the tunnel axis showed the subsiding of the settlement from the tunnel surrounding to the surface level. At the surface came on only a small amount of deformation. The comparison between the measuring axis in front of the protection wall and this one behind it showed no remarkable differences.

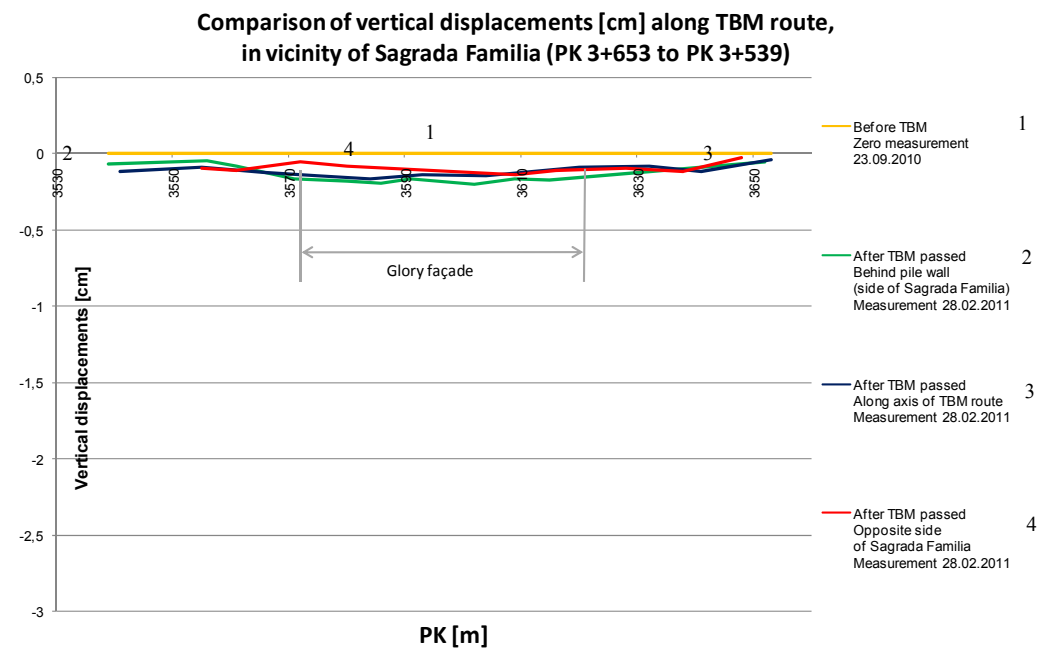

Figure 10: Measured settlement behind the bore pile wall in vicinity to Sagrada Familia during passing of the TBM (Jäger and Katzenbach [16]).

It can be stated that the settlement over the tunnel axis lay in the amount of the measuring precision but could be noted. The absolute size was, overall, between 1 and $2 \mathrm{~mm}$.

\subsection{Sagrada Familia}

The above stated tendency could be confirmed by the independent precision leveling in the basement of Sagrada Familia. The diagram in Figure 11: 11 shows the development of the settlement along the time axis. All measuring points are drawn one above the other. The magnitude of the measured settlement is the same like above mentioned. The results of the monitoring of the constructor could be confirmed by the measuring carried out independently by the authors.

The optical measuring at the Glory Façade showed a slight movement of the part separated by the vertical joint to the naive, but the amount was in the magnitude of the measuring precision. The installed inclinometers reacted very sensitive on dynamic accelerations by construction works inside the church. The sensors inhered in a temperature drift which had to be considered in the data 
evaluation. The drift should be tested in advance. Also the fastening steel angel for the sensor reacted sensitive on any acceleration.

The data recorded in the basement by precision leveling confirmed the tendency noticed with the leveling outside of the building.

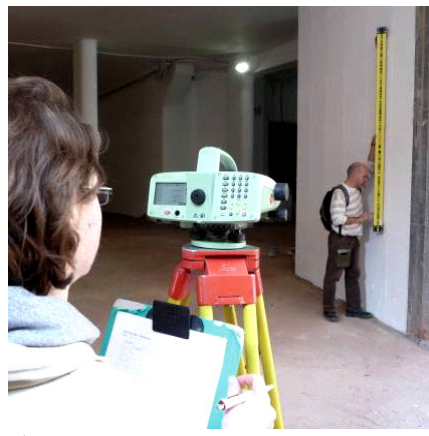

a)

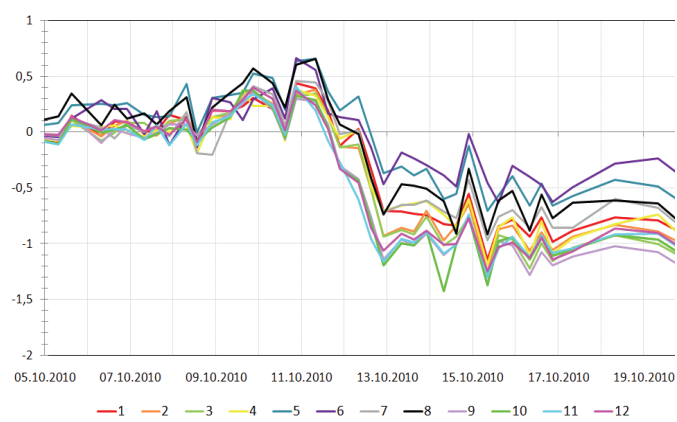

b)

Figure 11: a) Precision levelling. b) Results in $\mathrm{mm}$ perpendicular to the tunnel axis (all points drawn in one diagram - top curve - inside of the church, curve below closest distance to the tunnel axis).

The measured small movements of the cracks at the apse, the Nativity Façade and the beginning of the cloister were mostly caused by temperature influences and did not have any connection with the tunneling works.

\subsection{Comparison of predicted and measured results}

The following table shows the predicted and the measured values in a longitudinal section through the main naive of Sagrada Familia. All measured settlements laid beneath the predicted values.

There was no risk or impact at any time during the passing of the TBM along the Glory Façade of Sagrada Familia.

Table 1: $\quad$ Comparison of settlement values [16].

\begin{tabular}{|c|c|c|c|}
\hline \multicolumn{2}{|c|}{} & Tunnel axis & Glory Façade \\
\hline \multirow{3}{*}{$\begin{array}{c}\text { Predicted } \\
\text { settlement }\end{array}$} & Intecsa-Inarsa & 8 & 2 \\
\cline { 2 - 4 } & $\begin{array}{c}\text { INTEMAC max. } \\
(0 \% \text { mortar injection })\end{array}$ & 16 & 4 \\
\cline { 2 - 4 } & $\begin{array}{c}\text { INTEMAC min. } \\
(100 \% \text { mortar injection })\end{array}$ & 3 & 2 \\
\cline { 2 - 4 } & UPC & 11,5 & 2 \\
\cline { 2 - 4 } & $\begin{array}{c}\text { Buxaudé, Margarit, } \\
\text { Ferrando S.L.P. }\end{array}$ & 12,5 & 8,5 \\
\hline \multicolumn{2}{|c|}{ Recorded values } & 1,7 & 1,3 \\
\hline
\end{tabular}




\subsection{Casa Mila}

The monitoring of Casa Milà led in general to the same results like at the Church of Sagrada Familia. The extent of monitoring had been reduced because of the collected experiences during the passing of the TBM along Sagrada Familia.

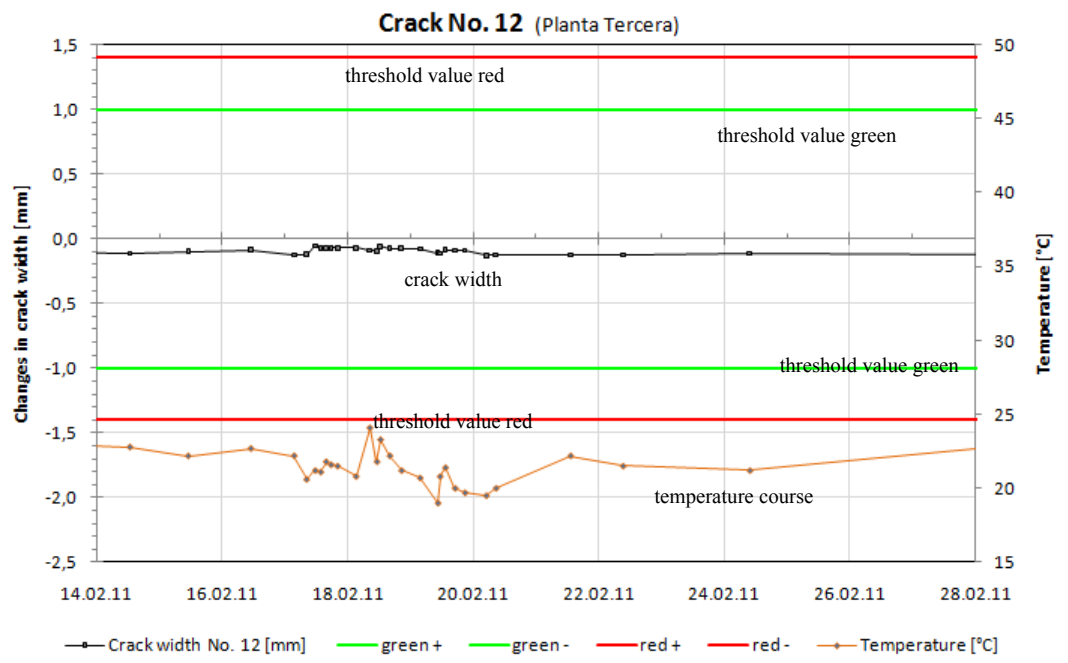

Figure 12: Measured crack width in a perpendicular wall to the tunnel axis during passing of the TBM at Casa Milà (Jäger and Katzenbach [16]).

Also in the case of Casa Milà the course of deformation from the middle axis of the tunnel to the inner region of the house led to such small deformations that the bore pile wall could not be activated. But she fulfilled its task as protecting wall for unforeseen events as contribution for reduction of the remaining risk considering the outstanding value of the heritage building.

\section{Summary}

Comparing the recorded vertical deformations with the different values calculated on the basis of various models and analysis methods can be seen that the predicted values are all below the measured ones (Table 1). In the Glory façade a reaction of the building on the tunnelling works could be noticed but in a very little amount. They had such a magnitude that at no time any risk for Sagrada Familia existed.

Overall, it can be stated that the reliability and accuracy of the precision levelling allowed a doubtless conclusion concerning the vertical displacements. With the installed levelling bolts further measurements for the observation of long term effects due to any reasons are possible in the future. 
The applied optical sensors of the OSMOS-Monitoring System showed an excellent performance with view on the sensibility and data recording. The system works with a self calibration after electricity interruption which is very helpful. But an uninterruptible electricity supply is recommended in any case. The measuring points and devices should be located on such places where no or only a minimum of impact due to the use of the building or due to construction works can be awaited.

The work with independent and redundant measuring systems proved once worth. This also can be said on the different measuring technologies. Only in the hot phase of measuring can be seen if a monitoring system is full appropriate or if it has some disadvantages. Also a comparison of different measuring precisions and influences of environment is possible.

For the execution of the monitoring threshold values for the measuring points are necessary as well as a specified management plan where all activities are listed which should be done in case of emergency.

For the determination of the threshold values known values are helpful but need an adoption for the special case under consideration of geometry and observed data from the beginning of the works. The application of the observational method according to EC 7 (CEN [19]) is recommended.

In principle can be said that the tunnelling works did not have any impact on the World heritage buildings Sagrada Familia and Casa Milà by the high precision of the tunnelling works, the independent check and supervision of the tunnel construction and the monitoring in the tunnel, above it and in the surrounding.

\section{Outlook}

For future comparable projects in vicinity to valuable heritage buildings or structures following experiences can be worthwhile

1. An independent check-proof of the project and the execution helps to guarantee the assumed safety level and to reduce the risk due to human failure or unforeseen and not detected facts (like soil uncertainties) (Dressel [23]). In the case of Cultural World Heritage, the necessary prerequisites should be established.

2. In the case of declarations for heritage buildings or structures e.g. such like for Cultural World Heritage, civil engineers with a preservation background should be involved very early to state which impacts on the structure any construction activities in the surrounding can have.

3. Threshold values for allowable deformations caused by construction activities nearby existing buildings are needed on the latest state of the art of numerical simulation and knowledge on the specific behaviour (see Burd [24] and Aye [26]). For outstanding and unique buildings and structures algorithm to come to such values should be available. 


\section{Acknowledgements and thanks}

In addition to the mentioned authors were involved in the monitoring from the team of Prof. Jäger: Peter Ruge, Peter Schöps, Alexander Peinelt, Eyas alKhateeb, Anke Eis, Christian Fuchs, Daniel Fucke, Dominic Geppert, Ferdinand Ghantus and Maximilian Hansen. From the side of the team of Rolf Kaatzenbach participated Matthias Vogler, Robert Dunaevskiy, Susanne Kurze, Dimitri Trifonov and others. The whole team thanks for the comradely collaboration with the construction and design department of Sagrada Familia especially the leading architect Jordi Bonet i Armengol and his co-worker Jordi Fauli.

The gratitude also holds true for the director of the project "L.A.V. MadridBarcelona-Figueres" Rafael Rodriguez Gutierrez, his assistant Jorge Laguna Potecali and all members of the adif-team. Also all other contributors and also the members of the Board of Experts should be thanked for their support and contributions.

\section{References}

[1] Madrid-Barcelona high-speed rail line. http://en.wikipedia.org/ wiki/Madrid-Barcelona_high-speed_rail_line (29.04.2011).

[2] Welterbeliste. http://whc.unesco.org/en/list. (05.06.2011).

[3] UNESCO-Welterbe. http://en.wikipedia.org/wiki/World_Heritage_Site (05.06.2011).

[4] Gaudí.

http://de.wikipedia.org/wiki/Antonio_Gaud\%C3\%AD (29.04.2011)

[5] Werke Gaudis. http://en.wikipedia.org/wiki/Antoni_Gaud\%C3\%AD (29.04.2011).

[6] Sagrada Familia. http://en.wikipedia.org/wiki/Sagrada_Fam\%C3\%A Dlia (05.06.2011).

[7] Bonet i Armengol, J.: Templo de la Sagrada Familia. Ed. Escudo de Oro, Barcelona 1999.

[8] Burry, M.; Coll Griffoll, J.; Gómez Serrano, J.: Sagrada Familia s. XXI. Gaudí ara / ahora / now. Edicions UPC, Barcelona 2008.

[9] Tomlow, J.: Das Modell. Antoni Gaudis Hängemodell und seine Rekonstruktion - Neue Erkenntnisse zum Entwurf für die Kirche der Colonia Güell. Mitt. des IL, Univ. Stuttgart. Hrsg. F. Otto, Nr. 34, Stuttgart 1989.

[10] Casa Milà. http://en.wikipedia.org/wiki/Casa_Mil\%C3\%A0 (05.06.2011).

[11] Asarta, F.: Restoration of La Pedrera. In: La Pedrera - Gaudí and his work, Fundacio Caixa Catalunya (ed.), Barcelona 2000.

[12] Hildesheim - Welterbestätten und Pufferzone. http://www.hildesheim.de /staticsite/staticsite.php? menuid=432\& topmenu=3 (29.04.2011).

[13] Documentation for the extension of the Cultural World Heritage of Gaudi by Sagrada Familia: Spanish Ministry for Culture/UNESCO-World Heritage Office, Madrid/Paris 2004/05. 
[14] DIN 1055-100: 2001-03: Einwirkungen auf Tragwerke. Grundlagen der Tragwerksplanung, Sicherheitskonzept und Bemessungsregeln. NA Bau im DIN e.V.: Berlin 2001.

[15] Tunnel Boring Machine. http://en.wikipedia.org/wiki/Tunnel_boring machine .

[16] Jäger, W.; Katzenbach, R. et al: Monitoring during tunnelling works in vicinity of Sagrada Familia and Casa Milà Barcelona Spain. High Speed Railway AVE Tunnel, Section Sants-Sagrera in Vicinity of UNESCO World Heritage Property "Works of Gaudí". Report: Independent Technical Expert's Documentation of the Passage of the Tunnel Boring Machine at the Temple of Sagrada Familia and Casa Milà. Barcelona, Spain, 08.06.2011.

[17] Peinelt, A.: Analyse der Tragstruktur der Casa Milá und Bewertung eines Monitoringprogramms im Zusammenhang mit dem Bau des ProvençaTunnels in Barcelona. Diplomarbeit. TU Dresden, Lehrstuhl Tragwerksplanung 2011.

[18] MINTRA-Grenzwerte für zulässige Setzungen und Verformungen an Gebäuden im Zusammenhang mit Aushub- und Tunnelarbeiten. Spanish Ministry for Economy. Madrid, o.J.

[19] EN 1997-1:2009-09: Eurocode 7: Geotechnical design. General rules. CEN, Brussels, 2009.

[20] Boscardin, D.M.; Cording, E.J.: Building response to excavation-induced settlement. ASCE-Journal of Geotechnical Engineering, Vol. 115, No. 1, Jan. 1989, S. 1-21. (and discussion/correction published in August 1990, Vol 116, No. 8 S. 636 f).

[21] Burland, J.B.; Wroth, C.P.: Settlement of Buildings and associated damages. In: Proc: Conf. on Settlement of Structures, Pentech Press, London 1974, S. 611 - 654.

[22] Bakeer, T.; Schöps, P.: Temple of La Sagrada Familia - Numerical Investigations. Short report - unpublished. Dresden University of Technology, Chair of Structural Design/ Jäger Ingenieure $\mathrm{GmbH}$ Radebeul, 2011.

[23] Dressel, B.: Die Rolle des Prüfingenieurs im System der vorbeugenden Gefahrenabwehr. Stahlbau 78 (2009), 3, S. 214 - 220.

[24] Burd, H.J.; Houlsby, G.T.; Augarde, C.E.: Modelling tunnelling-induced settlement of masonry buildings Proc. Instn Civ. Engrs, Geotech. Engng. 143 (2000) Jan. S. 17 -29.

[25] Rots, J.: The role of structural modelling in preserving Amsterdam architectural city heritage. Proc. of the Intn. Conf. on Historical Constructions, Guimaraes 2001, Ed. P.B. Lourenco \& P. Roca. S 685 695.

[26] Aye, Z.Z.; Karki, D.; Schulz, C.: Ground movement prediction and building damage risk-assessment for deep excavations and tunnelling works in Bangkok subsoil. In: Proc. Int. Symp. on Underground Excavation and Tunneling, February 2006, Bangkok. S. 281 - 297. 